\title{
Impacts of Job Demands on Nurses' Performance Working in Public Hospitals
}

\author{
${ }^{1}$ Abdullah Mohammad Al-Homayan, ${ }^{1}$ Faridahwati Mohd Shamsudin, \\ ${ }^{1}$ Chandrakantan Subramaniam and ${ }^{2}$ Rabiul Islam \\ ${ }^{1}$ College of Business, \\ ${ }^{2}$ School of Economics, Finance and Banking, College of Business, \\ University Utara Malaysia, 06010 UUM, Sintok, Kedah, Malaysia
}

Received 2013-07-31, Revised 2013-08-15; Accepted 2013-08-19

\begin{abstract}
Job demands refers to the degree to which the working environment contains stimuli that require some effort, which suggests that job demands may lead to negative consequences if they require additional effort to achieve work goals. The aim of the study is to analysis the impacts of job demands on nurses' performance working in public hospitals. In order to achieve the study objective, a survey conducted. Questionnaires distributed to the public sector hospital's manager in Saudi Arabia. The findings of the study turn out to be true; the study will contribute to both theory and practice. Through the present study, the researcher expects the findings to shed light on the research conducted regression to analysis the impacts of job demands on nurses' performance.
\end{abstract}

Keywords: Job Demand, Nurse, Performance, Interacting Effect

\section{INTRODUCTION}

\subsection{Job Demands}

In general, job demands refers to the degree to which the working environment contains stimuli that require some effort (Jones and Fletcher, 1996), which suggests that job demands may lead to negative consequences if they require additional effort to achieve work goals (Peeters et al., 2005). It also refers to aspects of the job that require sustained effort and, as such incur certain costs as a result (Beutell, 2010). Job demands can be physical, psychological, social, or organizational.

Job demands are usually divided into two: challenge job stressors and hindrance job stressors. The term "hindrance job stressors" refers to "unpleasant, undesirable and excessive" factors in the course of work which get in the way of the ability of an individual to achieve goals associated with the specific job that he or she does such as role conflict, role overload and role ambiguity and are viewed as negative aspects of job demands (Judge et al., 1998). On the other hand, the term "challenge job stressors" refers to stressors which have the potential to promote the employee's personal growth and career growth as well and may include factors like high levels of workload, time pressure and numerous responsibilities and are viewed as positive stressors due to their characteristic potential to reward the employee (Cohen-Charash and Spector, 2001).

The following discusses four types of job demands that are purportedly able to contribute to job stress and hence job performance. They are quantitative demands, physical demands, emotional demands and shift work. These job demands are selected as they reflect the job nurses do.

\subsection{Quantitative Demands}

Quantitative demand refers to the amount of work that individuals perceive is expected of them (Coetzer and Rothmann, 2007) within a little time and operationalized in terms of (high) work pace (Emmerik and Peeters, 2009). A concept associated with quantitative demand is workload. Broadly speaking, workload may refer to work time commitments such as the number of hours devoted to paid work and work-related activities (Jimmieson et al., 2004), but it has also been referred to Kedah, Malaysia 
as time pressure, in which individuals perceive they have too many things to do and not enough time to do them (Fronea et al., 1997). The two main dimensions of quantitative demands at work seem to be intensity (work pace), also referred to as work pressure (Kwakman, 2001) and extensity (number of working hours) (Kristensen et al., 2004).

The quantitative demands could lead to quantitative overloads, which is defined as the amount of work that exceeds what an individual can accomplish in a given period of time (Perrewe and Ganster, 1989). Further, role overload occurs when employees feel they are facing excessive quantitative demands (i.e., there is too much work to do in too little a time), excessive qualitative demands (i.e., they do not have the sufficient skills to do the work at hand), or both (Jex, 1998). Role conflict, defined as having two or more tasks that are incompatible, is also a contributor to workload (Tsutsumi et al., 2008).

\subsection{Physical Demands}

The nature of work has changed from agricultural to industrial and to knowledge-based. In conjunction, physical demands have either decreased or remained the same from highly industrialized work to work that mostly involves offering services (Kacmar et al., 2009). The term physical demand refers to stressors that are associated with the physical setting such as the humidity, lighting, temperature and noise. It is also referred to as the intensity of the effort that is required physically in the course of working (Nahrgang et al., 2011). It is operationalized to assess the extent to which the job requires strenuous movements like bending, physical strength, lifting, or carrying objects (Demerouti and Geurts, 2004).

In nursing, nurses regularly have to handle and lift patients (Tooren and Jonge, 2010). On top of that, nurses also tend to work in awkward positions, stand in a prolonged period of time and lift loads (Bakker et al., 2003). In short, nursing can be a highly physical, stressful and demanding job (McFadzean and McFadzean, 2005).

\subsection{Emotional Demands}

Emotional job demands refers to the affective component of work and the degree to which one has to be face emotionally stressful situations because of one's work (Emmerik and Peeters, 2009). It is also defined as the frequency one is exposed to emotionally demanding situations (Bakker et al., 2005) and to those aspects of the job that require sustained emotional effort because of (extensive) contacts with others (Vegchel et al., 2004) and clients (De Jonge and Dormann, 2003).
Emotional demands at the work place consist of the aspects of works which require constant emotional input from the employees mostly as a result of interactions with clients. Workers in the human services sector are normally faced with a myriad of problems facing their fellow human beings and problems may arise in the course of their work as they relate with their clients (Karriker and Williams, 2009). These types of jobs demand that the workers show an appropriate emotional response which he or she may not honestly feel (Michiel et al., 1998). Generally, emotional and psychological demands have increased with the change in the nature of work from highly industrialized work to work that mostly involves offering services (Kacmar et al., 2009), which is clientoriented and usually involves intensive application of information technology tools (Witt et al., 2002).

\subsection{Shift Work}

In modern society, shift work has become a very common phenomenon. Shift work refers to a work arrangement whereby employees go to work in turns to ensure that the services being provided are available around the clock (Karriker and Williams, 2009). It is also defined as working outside the normal daytime hours (Rosa and Colligan, 1997), in which at least $50 \%$ of the work is done after 8:00-16:00 h (Hedges and Sekscenski, 1979). It also involves part-time work and weekend work (Costa, 2003). Nightshift is a common work schedule in health environments (Smith et al., 2007).

Most of the hospitals throughout the world besides those in the Middle East and Asia ensure that they are constantly staffed through the shift work method (Rotundo and Sackett, 2002). This ensures that there are enough healthcare personnel for the care of the patients at all times (Cook et al., 1979). While the doctors and the subordinate staff may not always be at work especially at night except in cases of emergencies, there are always nurses at any hospitals at any time which means that they operate in shifts in comparison to other employees at the hospital (Schmidt and Hunter, 1998). But according to Monk and Folkard (1985), employee performance generally tends to be worse on the night shift as those who have to work in a night shift may also suffer from sleep deprivation (Rose, 1984).

\section{MATERIALS AND METHODS}

The theoretical relationship between job demands and nurses' performance can be schematically diagrammed as shown in Fig. 1. The first independent variable in the present study is job demands which comprise four factors namely quantitative demands, physical demands, emotional demands and shift work. 


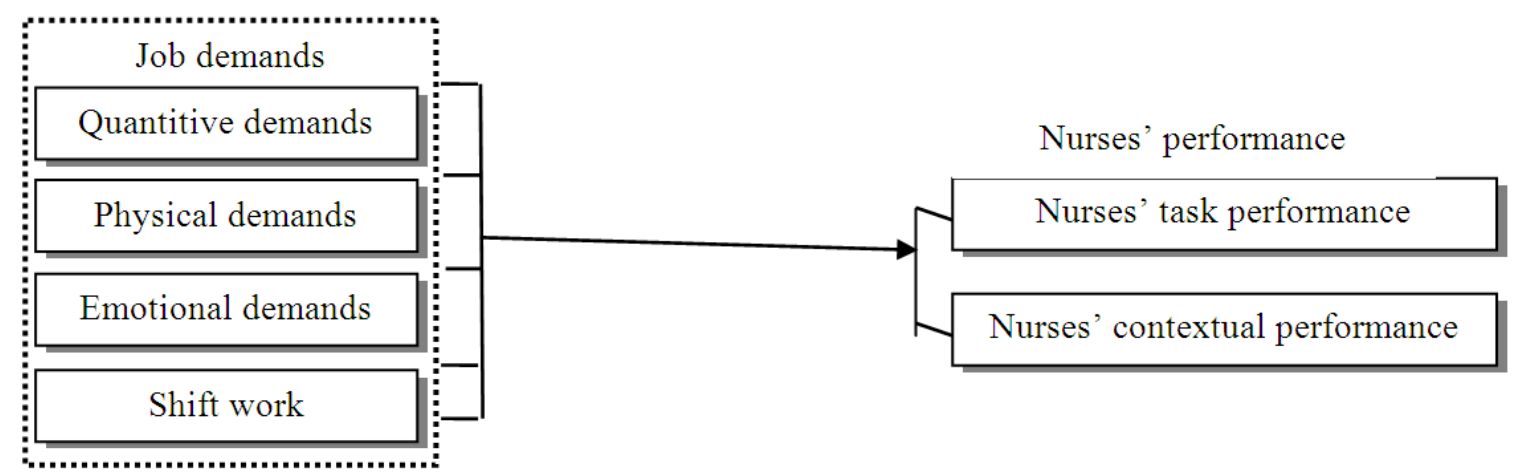

Fig. 1. Theoretical framework

The dependent variable is nurses' performance. In brief, as shown in Fig. 1, job demands are expected to produce a response from employees at work such that job demands will make employees feel stressful but job resources will decrease job stress. For instance, the more demanding their job is, the more likely they will be experiencing work stress. However, when employees perceive that their job is interesting and challenging, the less stress they will experience.

\subsection{Pilot Study}

A pilot study can be described as a small-scale project that culls data from respondents that are similar to the target respondents of the study (Zikmund et al., 2012). It normally serves as a guide to the researcher for his/her actual larger study or to examine the ambiguous aspects of the research to find out whether the procedures will work as intended. In other words, pilot studies are important because they refine survey questions and reduce flaws in the study (Zikmund et al., 2012). Furthermore, the pilot study's importance lies in the fact that it improves the questionnaires (Neuman, 1997). Normally, the size of the pilot study ranges from 25-100 subjects (Cooper and Schindler, 2008).

The researcher examined the questionnaire instruments' reliability. The present study suggested that the threshold of an acceptable level of reliability is at least 0.70, according to Hair and Anderson (2010); Nunnally (1978) and Zikmund et al. (2012), in which a reliability estimate of 0.7 or higher suggests a good reliability. Table 1 shows the Cronbach's alpha values of the variables used in pilot study. As shown, the alpha values ranged from 0.735 to 0.943 . These values were higher than the threshold value of 0.70 , indicating that the instruments used to measure the main variables were reliable.
Table 1. Result of cronbach's alphas of the main variables in pilot study

\begin{tabular}{lll}
\hline $\begin{array}{l}\text { Number } \\
\text { of items }\end{array}$ & Variables & Alpha \\
\hline 5 & Quantitative Demands (QD) & 0.745 \\
8 & Physical Demands (PD) & 0.899 \\
4 & Emotional Demands (ED) & 0.735 \\
2 & Shift Work (SW) & 0.846 \\
23 & Nurses' Task Performance (NTP) & 0.943 \\
18 & Nurses' Contextual Performance (NCP) & 0.922 \\
\hline
\end{tabular}

\section{RESULTS}

\subsection{Factor Analysis for Job Demand Construct}

As indicated in Table 2, to assess the underlying structure of job demand measure, 14 items were submitted to principle component method and varimax rotation analysis. The 14 items achieved more than 0.5 communalities and loaded on one factor. The KaiserMeyer-Olkin measures of sampling adequacy (KMO) for the single dimension solution was 0.98 , with chi-square of Bartlett's test of sphericity of 10210.22 , degrees of freedom of 91.00 and was significant at 0.000 . The variance explained was $76.59 \%$ with extracted factors eigenvalue of more than 1 . This indicates that the data were suitable for factor analysis (Hair and Anderson, 2010).

\subsection{Factor Analysis for Nurses' Performance Construct}

Nurses' performance construct dimensions were measured using 41 averaged items. A principle component factor analysis using varimax rotation was then conducted on the 41 items to determine which items should group to form what dimensions. The criteria developed by Igbaria et al. (1995) was used for cross loading, that is, a given item should load 0.50 or higher on a specific factor and have a loading no higher than 0.35 on other factors. 
Table 2. Summary of factor analysis of job demands construct $(n=632)$

\begin{tabular}{|c|c|c|c|c|}
\hline \multirow[b]{2}{*}{ Items } & \multicolumn{4}{|c|}{ Components } \\
\hline & 1 & 2 & 3 & 4 \\
\hline \multicolumn{5}{|l|}{ Factor 1: Physical demands } \\
\hline 1. Bedding and positioning patients & 0.579 & -0.238 & -0.041 & 0.197 \\
\hline 2. Transferring or carrying patients & 0.742 & -0.169 & -0.013 & -0.008 \\
\hline 3. Lifting patients in bed without aid & 0.774 & -0.104 & 0.001 & -0.069 \\
\hline 4. Mobilizing patients & 0.744 & -0.104 & -0.072 & 0.044 \\
\hline 5. Clothing patients & 0.758 & -0.068 & 0.004 & 0.115 \\
\hline 6. Helping with feeding & 0.737 & -0.126 & -0.089 & 0.005 \\
\hline 7. Making beds & 0.787 & -0.128 & 0.011 & 0.038 \\
\hline 8. Pushing patient's beds, food trolleys, or laundry trolleys & 0.774 & -0.119 & -0.027 & 0.030 \\
\hline \multicolumn{5}{|l|}{ Factor 2: Quantitative demands } \\
\hline 1. How often do you lack time to complete all your work tasks? & -0.194 & 0.792 & 0.037 & 0.077 \\
\hline 2. Can you pause in your work whenever you want? & -0.153 & 0.803 & 0.040 & 0.057 \\
\hline 3. Do you have to work very fast? & -0.162 & 0.776 & -0.041 & 0.006 \\
\hline 4. Is your workload unevenly distributed so that things pile up? & -0.212 & 0.762 & 0.001 & -0.006 \\
\hline 5. Do you have enough time to talk to patients? & -0.154 & 0.814 & 0.021 & 0.064 \\
\hline \multicolumn{5}{|l|}{ Factor 3: Emotional demands } \\
\hline 1. Death & -0.078 & -0.013 & 0.741 & 0.052 \\
\hline 2. Illness or any other human suffering & -0.098 & 0.003 & 0.765 & 0.017 \\
\hline 3. Aggressive patients. & -0.055 & $-1.422 \mathrm{E}-5$ & 0.752 & 0.032 \\
\hline 4. Troublesome patients' in their work & 0.041 & 0.054 & 0.768 & -0.103 \\
\hline \multicolumn{5}{|l|}{ Factor 4: Shift work } \\
\hline $\begin{array}{l}\text { 1. During the last month, approximately how many } \\
\text { times did you work more than } 8 \text { hours per shift? }\end{array}$ & 0.099 & 0.113 & 0.002 & 0.927 \\
\hline $\begin{array}{l}\text { 2. During the last month, how often did you } \\
\text { work two shifts, back to back? }\end{array}$ & 0.119 & 0.079 & -0.013 & 0.904 \\
\hline Eigenvalues & 5.160 & 2.71 & 1.92 & 1.010 \\
\hline Percentage of variance Explained $=68.83 \%$ & 12.640 & 8.86 & 6.29 & 4.810 \\
\hline Kaiser-Meyer-Olkin Measure of Sampling Adequacy & 0.890 & & & \\
\hline Bartlett's Test of Sphericity Approx. Chi-Square & 12808.520 & & & \\
\hline df & 703.000 & & & \\
\hline Sig & 0.000 & & & \\
\hline
\end{tabular}

Two items were deleted after applying this criterion. The Kaiser-Meyer-Olkin criterion was applied to extract the number of factors with only an eigenvalues equal or greater than one can be extracted (Kaiser, 1960). The result of factor analysis demonstrated eight factors with an eigenvalue of more than 1 . The results are presented in Table 3.

The output in Table 3 shows that the KaiserMeyer-Olkin measures of sampling adequacy (KMO) for the eight dimensions solution was 0.95 , with a significant Bartlett's Test of Sphericity ( Sig $=0.000)$. This indicates that the data were suitable for factor analysis (Coakes et al., 2009). Hair and Anderson (2010) also stress that in social science research it is common to consider a solution that accounts for $60 \%$ or, in some instances, even less, of the total variance as satisfactory.
In the present study, factor loading in the components met the criteria by Igbaria et al. (1995), that is, a given item should load 0.50 or higher on a specific factor and have a loading no higher than 0.35 on other factors.

\subsection{Reliability Analysis}

The following section discusses the results of reliability. Reliability analysis was performed on the 12 dimensions extracted (i.e., quantitative demands, physical demands, emotional demands, shift work, provision of information, coordination of care, provision of support, technical care, interpersonal support, job task support, compliance, volunteering for additional duties). Cronbach's alpha coefficient was computed for each variable and presented in Table 4. 
Table 3. Summary of factor analysis for nurses' performance construct $(\mathrm{N}=632)$

\begin{tabular}{|c|c|c|c|c|c|c|c|c|}
\hline \multirow[b]{2}{*}{ Items } & \multicolumn{8}{|c|}{ Components } \\
\hline & 1 & 2 & 3 & 4 & 5 & 6 & 7 & 8 \\
\hline \multicolumn{9}{|l|}{$\begin{array}{l}\text { Factor 1: Provision of information } \\
\text { (Nurses' task performance) }\end{array}$} \\
\hline $\begin{array}{l}\text { 1. Explaining to patients what to } \\
\text { expect when they leave the hospital }\end{array}$ & 0.641 & 0.208 & 0.127 & 0.169 & 0.148 & 0.203 & 0.053 & 0.157 \\
\hline 2. Providing instructions for care at home & 0.733 & 0.090 & 0.185 & 0.189 & 0.097 & 0.156 & 0.120 & 0.119 \\
\hline $\begin{array}{l}\text { 3. Explaining to families what to do if the patient's } \\
\text { problems or symptoms continue, get worse, or return }\end{array}$ & 0.789 & 0.123 & 0.200 & 0.135 & 0.069 & 0.121 & 0.057 & 0.157 \\
\hline $\begin{array}{l}\text { 4. Explaining to patients when they can resume } \\
\text { normal activities, such as going to work or driving a car }\end{array}$ & 0.789 & 0.142 & 0.133 & 0.124 & 0.108 & 0.057 & 0.043 & 0.087 \\
\hline $\begin{array}{l}\text { 5. Providing appropriate information to } \mathrm{f} \\
\text { amilies about nursing procedures performed }\end{array}$ & 0.730 & 0.204 & 0.187 & 0.100 & 0.193 & 0.091 & 0.110 & 0.053 \\
\hline $\begin{array}{l}\text { 6. Communicating to patients the } \\
\text { purpose of nursing procedures }\end{array}$ & 0.697 & 0.116 & 0.192 & 0.141 & 0.274 & 0.190 & 0.112 & 0.067 \\
\hline $\begin{array}{l}\text { 7. Informing patients of the possible } \\
\text { side-effects of nursing procedure } \\
\text { Factor 2: Job-task support } \\
\text { (Nurses' contextual performance) }\end{array}$ & 0.657 & 0.101 & 0.012 & 0.152 & 0.250 & 0.325 & 0.063 & 0.092 \\
\hline 1. Making special arrangements for a patient's family. & 0.121 & 0.653 & 0.035 & 0.209 & 0.244 & 0.120 & 0.070 & 0.122 \\
\hline 2. Staying late to help families. & 0.128 & 0.814 & 0.048 & 0.071 & 0.119 & -0.048 & 0.010 & 0.042 \\
\hline 3. Taking extra time to respond to a family's needs. & 0.141 & 0.835 & 0.000 & 0.108 & 0.127 & 0.032 & 0.037 & 0.057 \\
\hline 4. Making special arrangements for the patient. & 0.171 & 0.641 & 0.142 & 0.186 & 0.113 & 0.151 & 0.172 & 0.237 \\
\hline 5. Staying late to help patients. & 0.147 & 0.600 & 0.174 & 0.210 & 0.003 & 0.039 & 0.286 & 0.089 \\
\hline $\begin{array}{l}\text { 6. Taking extra time to respond to a patient's needs. } \\
\text { Factor 3: Technical care (Nurses' task performance) }\end{array}$ & 0.142 & 0.614 & 0.206 & 0.202 & 0.075 & 0.020 & 0.181 & 0.164 \\
\hline $\begin{array}{l}\text { 1. Taking patient observations } \\
\text { (e.g., blood pressure, pulse, temperature) }\end{array}$ & 0.162 & -0.014 & 0.654 & 0.257 & 0.173 & 0.257 & 0.112 & 0.118 \\
\hline $\begin{array}{l}\text { 2. Assisting patients with activities of daily } \\
\text { living (e.g., showering, toileting and feeding) }\end{array}$ & 0.122 & 0.203 & 0.739 & 0.058 & 0.235 & 0.086 & 0.091 & 0.044 \\
\hline 3. Developing a plan of nursing care for patients & 0.201 & 0.205 & 0.708 & 0.135 & 0.221 & 0.197 & 0.070 & 0.136 \\
\hline 4. Administering medications and treatments & 0.228 & 0.006 & 0.791 & 0.219 & 0.094 & 0.181 & 0.073 & 0.145 \\
\hline 5. Evaluating the effectiveness of nursing care & 0.231 & 0.133 & 0.744 & 0.193 & 0.146 & 0.121 & 0.080 & 0.162 \\
\hline $\begin{array}{l}\text { Factor 4: Interpersonal support } \\
\text { (Nurses' contextual performance) }\end{array}$ & & & & & & & & \\
\hline 1. Raising morale of other nurses in the unit. & 0.271 & 0.189 & 0.091 & 0.660 & 0.162 & 0.156 & 0.123 & 0.204 \\
\hline $\begin{array}{l}\text { 2. Helping nurses in the unit to resolve work problems. } \\
\text { 3. Consulting amongst each other when actions }\end{array}$ & 0.228 & 0.117 & 0.232 & 0.703 & 0.119 & 0.239 & 0.153 & 0.161 \\
\hline might affect other nurses in the unit. & 0.154 & 0.206 & 0.254 & 0.705 & 0.106 & 0.163 & 0.130 & 0.072 \\
\hline 4. Taking time to meet unit nurses' emotional needs. & 0.089 & 0.257 & 0.127 & 0.708 & 0.244 & 0.000 & 0.106 & 0.084 \\
\hline $\begin{array}{l}\text { 5. Volunteering to share special knowledge or } \\
\text { expertise with other nurses in the unit }\end{array}$ & 0.216 & 0.187 & 0.173 & 0.562 & 0.165 & 0.150 & 0.245 & 0.243 \\
\hline $\begin{array}{l}\text { 6. Helping nurses in the unit to catch up on their work. } \\
\text { Factor 5: Provision of support (Nurses' task performance) }\end{array}$ & 0.178 & 0.233 & 0.144 & 0.562 & 0.170 & 0.166 & 0.178 & 0.223 \\
\hline 1. Showing care and concern to families. & 0.251 & 0.120 & 0.246 & 0.314 & 0.625 & 0.172 & 0.064 & 0.115 \\
\hline 2. Listening to families' concerns. & 0.275 & 0.117 & 0.231 & 0.169 & 0.687 & 0.230 & 0.106 & 0.113 \\
\hline 3. Taking time to meet families' emotional needs. & 0.232 & 0.286 & 0.073 & 0.153 & 0.758 & 0.093 & 0.112 & 0.098 \\
\hline 4. Listening to patients' concerns. & 0.257 & 0.126 & 0.313 & 0.169 & 0.611 & 0.230 & 0.108 & 0.168 \\
\hline $\begin{array}{l}\text { 5. Taking time to meet the emotional needs of patients. } \\
\text { Factor 6: Coordination of care (Nurses' task performance) }\end{array}$ & 0.160 & 0.181 & 0.316 & 0.179 & 0.653 & 0.149 & 0.047 & 0.177 \\
\hline $\begin{array}{l}\text { 1. Explaining to nurses in the unit the } \\
\text { nature of the patient's condition }\end{array}$ & 0.314 & 0.087 & 0.081 & 0.126 & 0.123 & 0.732 & 0.087 & 0.026 \\
\hline $\begin{array}{l}\text { 2. Reporting the critical elements of patients' } \\
\text { situations when turning over work shifts }\end{array}$ & 0.147 & 0.067 & 0.241 & 0.199 & 0.105 & 0.774 & 0.125 & 0.027 \\
\hline
\end{tabular}


Table 3. Continue

\begin{tabular}{|c|c|c|c|c|c|c|c|c|}
\hline $\begin{array}{l}\text { 3. Ensuring all members of the nursing unit are } \\
\text { familiar with the patient's recent medical history }\end{array}$ & 0.191 & 0.099 & 0.174 & 0.073 & 0.198 & 0.769 & 0.088 & 0.099 \\
\hline $\begin{array}{l}\text { 5. Informing all nurses in the unit about } \\
\text { patient tests and their results }\end{array}$ & 0.203 & -0.082 & 0.294 & 0.215 & 0.196 & 0.619 & 0.152 & 0.070 \\
\hline \multicolumn{9}{|l|}{ Factor 7: Compliance (Nurses' contextual performance) } \\
\hline $\begin{array}{l}\text { 1. Complying with hospital rules, regulations and } \\
\text { procedures, even when no one is watching }\end{array}$ & 0.048 & 0.096 & 0.172 & 0.208 & 0.056 & 0.140 & 0.772 & 0.096 \\
\hline $\begin{array}{l}\text { 2. Representing the hospital favorably to } \\
\text { individuals outside the hospital }\end{array}$ & 0.109 & 0.256 & 0.008 & 0.147 & 0.099 & 0.104 & 0.795 & 0.124 \\
\hline $\begin{array}{l}\text { 3. Making sure that materials and } \\
\text { equipment are not wasted }\end{array}$ & 0.187 & 0.132 & 0.119 & 0.168 & 0.121 & 0.119 & 0.744 & 0.165 \\
\hline \multicolumn{9}{|l|}{$\begin{array}{l}\text { Factor 8: Volunteering for additional duties } \\
\text { (Nurses' contextual performance) }\end{array}$} \\
\hline $\begin{array}{l}\text { 1. Volunteering to participate on committees } \\
\text { within the hospital that are not compulsory }\end{array}$ & 0.176 & 0.230 & 0.138 & 0.190 & 0.122 & 0.044 & 0.144 & 0.752 \\
\hline $\begin{array}{l}\text { 2. Attending and participating in } \\
\text { meetings regarding the hospital }\end{array}$ & 0.198 & 0.212 & 0.181 & 0.192 & 0.193 & 0.091 & 0.166 & 0.736 \\
\hline $\begin{array}{l}\text { 3. Making innovative suggestions to } \\
\text { improve the overall quality of the department }\end{array}$ & 0.168 & 0.128 & 0.188 & 0.245 & 0.150 & 0.067 & 0.135 & 0.771 \\
\hline Eigenvalues & 15.040 & 2.850 & 2.13 & 1.71 & 1.470 & 1.32 & 1.190 & 1.020 \\
\hline Percentage of Variance Explained $=68.50 \%$ & 12.350 & 9.820 & 9.63 & 9.25 & 7.960 & 7.51 & 6.000 & 5.980 \\
\hline Kaiser-Meyer-Olkin Measure of Sampling Adequacy & 0.950 & & & & & & & \\
\hline Bartlett's Test of Sphericity Approx. Chi-Square & 15531.180 & & & & & & & \\
\hline$D f$ & 741.000 & & & & & & & \\
\hline Sig. & 0.000 & & & & & & & \\
\hline
\end{tabular}

Table 4. Cronbach's alphas of the study variables after factor analysis $(\mathrm{n}=632)$

\begin{tabular}{|c|c|c|c|}
\hline Number of items & Variables & Alpha & $\begin{array}{l}\text { Items dropped } \\
\text { after factor analysis }\end{array}$ \\
\hline 5 & Quantitative Demands (QD) & 0.88 & - \\
\hline 8 & Physical Demands (PD) & 0.90 & - \\
\hline 4 & Emotional Demands (ED) & 0.77 & - \\
\hline 2 & Shift Work (SW) & 0.89 & - \\
\hline 7 & Provision of Information (PI) & 0.91 & - \\
\hline 4 & Coordination of Care (CC) & 0.85 & 1 \\
\hline 5 & Provision of Support (PS) & 0.89 & 1 \\
\hline 5 & Technical Care (TC) & 0.89 & - \\
\hline 6 & Interpersonal support (IntSup) & 0.88 & - \\
\hline 6 & Job-Task support (J-TSup) & 0.86 & - \\
\hline 3 & Compliance (Com) & 0.81 & - \\
\hline 3 & Volunteering for Additional Duties (VAD) & 0.85 & - \\
\hline \multicolumn{4}{|c|}{$\begin{array}{l}\text { Note: }{ }^{a} 1=\text { hardly ever, } 2=\text { seldom, } 3=\text { a few times, } 4=\text { many times, } 5=\text { always; }{ }^{b} 1=0-1 \text { time a day, } 2=2-4 \text { times a day, } 3=5-7 \\
\text { times a day, } 4=8-10 \text { times a day, } 5=>10 \text { times a day; }{ }^{c} 1=\text { never, } 2=\text { seldom, } 3=\text { sometimes, } 4=\text { often, } 5=\text { always; }{ }^{d} 1=\text { not at all, } \\
2=\text { a few times, } 3=\text { sometimes, } 4=\text { quite a lot, } 5=\text { a great deal; }{ }^{e} 1=\text { strongly disagree, } 2=\text { disagree, } 3=\text { neutral, } 4=\text { agree, } 5= \\
\text { strongly agree; }{ }^{f} 1=\text { none of the time, } 2=\text { a little bit of time, } 3=\text { some of the time, } 4=\text { a lot of the time, } 5=\text { all of the time; }{ }^{g} 1=\text { Much } \\
\text { below average, } 2=\text { Somewhat below average, } 3=\text { Average, } 4=\text { Somewhat above average, } 5=\text { Much above average; }{ }^{h} 1=\text { not at all, } 2 \\
=\text { minimally, } 3=\text { somewhat, } 4=\text { quite a bit, } 5=\text { a great deal }\end{array}$} \\
\hline
\end{tabular}

The results of the reliability of the measurement in this study appeared acceptable. Internal consistency of the scales ranged from 0.77 (emotional demands) to 0.90 (physical demand), which suggest the specified indicators were sufficient for use (Hair and Anderson, 2010; Zikmund et al., 2012). The result suggests that the variables were appropriate for further analysis.

\section{DISCUSSION}

\subsection{Descriptive Analysis}

The general statistical description of variables used in this study was examined by using descriptive analysis. Statistical values of means, standard deviation, minimum and maximum were calculated for the independent 
variables, the mediating variable, the moderating variable and the dependent variable. The results of these statistical values are shown in Table 5.

Table 5 presents the summary of means of the independent variables, mediating variable, moderating variable and dependent variables. The mean for all variables was between 1.27 and 3.97. In general, close to half of the variables $(47.37 \%)$ had moderate mean values between 2.34 and 3.67 (skill variety, feedback, job security, job stress, organizational support, provision of information, provision of support, job-task support and volunteering for additional duties). On the other hand, $31.58 \%$ of the variables had mean values of more than 3.67 (task significance, task identity, coordination of care, technical care, interpersonal support and compliance) and $21.05 \%$ had low mean values of less than 2.34 (quantitative demands, physical demands, emotional demands and shift work). Technical care had the highest mean of 3.97 with a standard deviation of 0.78 and minimum and maximum scores of 1.80 and 5.00, respectively, while shift work scored the lowest mean of 1.27 with a standard deviation of 0.43 and minimum and maximum scores of 1.00 and 2.00, respectively.

\subsection{Interacting Effects}

In this study, evaluation on assumptions of linearity, homoscedasticity, normality, independence of the error terms and multicollinearity revealed no significant violation of assumption. Table 6 shows that all of the variables' skewness and Kurtosis statistics were between the normal distribution $( \pm 1.96, \pm 2.58)$ of the standard deviations (Hair and Anderson, 2010).

No exhibit of any nonlinear pattern to the residuals, thus ensuring that the overall equation is linear. In details, the result of linearity test for the relationship between the independent variables (job demands) and the dependent variable (eight dimensions of nurses' performance) through scatter plot diagrams shows no evidence of nonlinear pattern to the residuals. No pattern of increasing or decreasing residuals, which indicates homoscedasticity in the multivariate case. Because the values fall along the diagonal with no substantial or systematic departures, the residuals were considered to represent a normal distribution. The Durbin-Watson values of $1.84,1.87,1.98,1.86,1.75,1.84,1.85$ and 1.76 met the general rule of thumb, suggesting that the assumptions of independence of the error terms were not violated. Finally the Variance Inflation Factor (VIF) value did not exceed 10 and tolerance value was not lower than 0.10 , thus exhibiting no apparent collinearity problem.

\subsection{Effect of Job Demands on Nurses' Performance (Task and Contextual)}

This study requires an analysis to examine the relationship between the independents variables of job demands, namely quantitative demands, physical demands, emotional demands, shift work and the dependent variables of nurses' performance namely nurses' task and contextual performance (i.e., provision of information, coordination of care, provision of support, technical care, interpersonal support, job-task support, compliance and volunteering for additional duties).

A standard multiple regression analysis was conducted. The study used an "enter" method to perform the regression analysis. The multiple correlation (R), squared multiple correlation $\left(\mathrm{R}^{2}\right)$ and adjusted squared multiple correlation $\left(\operatorname{adj} R^{2}\right)$ indicate how well the combination of the independent variables predict the dependent variable is shown in Table 7.

The main purpose of the present study was to examine the determinants of job performance among nurses in public hospitals in the Kingdom of Saudi. Specifically, the study examined the direct relationship of job demands (i.e., physical demands, emotional demands, quantitative demands and shift work) and nurses' job performance. Towards this end, a number of research hypotheses were formulated. In general, the present study has provided empirical support for the determinants of nurses' job performance.

The present study hypothesized that job demands affect nurse's performance in public hospitals in Saudi Arabia. Job demands in the present study refer to "those physical, psychological, social, or organizational aspects of the job that require sustained physical or psychological (cognitive and emotional) effort or skills and are therefore associated with certain physiological or psychological costs" (Demerouti et al., 2001). In the present study, job demands were operationalized by four dimensions of quantitative demands, physical demands, emotional demands and shift work. Job resources, in the present study, was defined as "those physical, psychological, social, or organizational aspects of the job that (a) are functional in achieving work goals; (b) reduce job demands and the associated physiological and psychological costs; or (c) stimulate personal growth, learning and development" (Demerouti et al., 2001). Here, skill variety, task significance, task identity, feedback and job security were employed to measure job resources. 
Table 5. Mean, standard deviation, minimum and maximum of job demands and nurses job performance

\begin{tabular}{|c|c|c|c|c|}
\hline Variables & Mean & SD & Minimum & Maximum \\
\hline Quantitative Demands (QD) ${ }^{\mathrm{a}}$ & 2.09 & 0.69 & 1.00 & 4.00 \\
\hline Physical Demands (PD) ${ }^{\mathrm{b}}$ & 2.13 & 0.63 & 1.00 & 3.75 \\
\hline Emotional Demands $(E D)^{c}$ & 1.93 & 0.56 & 1.00 & 3.25 \\
\hline Shift Work $(\mathrm{SW})^{\mathrm{d}}$ & 1.27 & 0.43 & 1.00 & 2.00 \\
\hline Provision of Information $(\mathrm{PI})^{\mathrm{g}}$ & 3.45 & 0.79 & 1.57 & 5.00 \\
\hline Coordination of Care $(\mathrm{CC})^{\mathrm{g}}$ & 3.82 & 0.80 & 1.60 & 5.00 \\
\hline Provision of Support (PS) ${ }^{\mathrm{g}}$ & 3.60 & 0.79 & 1.40 & 5.00 \\
\hline Technical Care (TC) $)^{\mathrm{g}}$ & 3.97 & 0.78 & 1.80 & 5.00 \\
\hline Interpersonal Support (IntSup) ${ }^{\mathrm{h}}$ & 3.73 & 0.82 & 1.50 & 5.00 \\
\hline Job-Task Support (JTSup) ${ }^{\mathrm{h}}$ & 3.24 & 0.78 & 1.33 & 5.00 \\
\hline Compliance $(\mathrm{Com})^{\mathrm{h}}$ & 3.72 & 0.84 & 1.67 & 5.00 \\
\hline Volunteering for Additional Duties (VAD) ${ }^{\mathrm{h}}$ & 3.62 & 0.84 & 1.33 & 5.00 \\
\hline
\end{tabular}

Note: ${ }^{\mathrm{a}} 1=$ hardly ever, $2=$ seldom, $3=$ a few times, $4=$ many times, $5=$ always; ${ }^{b} 1=0-1$ time a day, $2=2-4$ times a day, $3=5-7$ times a day, $4=8$-10 times a day, $5=>10$ times a day; ${ }^{\mathrm{c}} 1=$ never, $2=$ seldom, $3=$ sometimes, $4=$ often, $5=$ always; ${ }^{\mathrm{d}} 1=$ not at all, $2=$ a few times, $3=$ sometimes, $4=$ quite a lot, $5=$ a great deal; ${ }^{\mathrm{e}} 1=$ strongly disagree, $2=$ disagree, $3=$ neutral, $4=$ agree, $5=$ strongly agree; ${ }^{\mathrm{f}} 1=$ none of the time, $2=$ a little bit of time, $3=$ some of the time, $4=$ a lot of the time, $5=$ all of the time; ${ }^{\mathrm{g}} 1=$ Much below average, $2=$ Somewhat below average, $3=$ Average, $4=$ Somewhat above average, $5=$ Much above average; ${ }^{{ }^{h}} 1=$ not at all, 2 $=$ minimally, $3=$ somewhat, $4=$ quite a bit, $5=$ a great deal

Table 6. Statistic values of skewness and kurtosis (descriptive statistics) $(\mathrm{n}=632)$

\begin{tabular}{lcc}
\hline Variables & Skewness & Kurtosis \\
\hline Quantitative demands (QD) & 0.84 & -0.33 \\
Physical demands (PD) & 0.31 & -0.95 \\
Emotional demands (ED) & 0.87 & -0.20 \\
Shift work (SW) & 1.01 & -0.86 \\
Provision of information (PI) & -0.05 & -0.65 \\
Coordination of care (CC) & -0.42 & -0.46 \\
Provision of support (PS) & 0.08 & -0.72 \\
Technical care (TC) & -0.48 & -0.67 \\
Interpersonal support (IntSup) & -0.23 & -0.68 \\
Job-task support (JTSup) & 0.16 & -0.34 \\
Compliance (Com) & -0.35 & -0.65 \\
Voluntering for additional duties (VAD) & -0.28 & -0.74 \\
\hline
\end{tabular}

Table 7. Multiple regression analysis: Job demands and nurses' task performance and contextual performance $(\mathrm{n}=632)$

\begin{tabular}{|c|c|c|c|c|c|c|c|c|}
\hline \multirow[b]{2}{*}{ Independent variables } & \multicolumn{3}{|c|}{ Task performance } & \multicolumn{2}{|c|}{ Standardized beta } & \multicolumn{3}{|c|}{ Contextual performance } \\
\hline & $\begin{array}{l}\text { Provision of } \\
\text { information }\end{array}$ & $\begin{array}{l}\text { Coordination } \\
\text { of care }\end{array}$ & $\begin{array}{l}\text { Provision } \\
\text { of support }\end{array}$ & $\begin{array}{l}\text { Technical } \\
\text { care }\end{array}$ & $\begin{array}{l}\text { Interpersonal } \\
\text { support }\end{array}$ & $\begin{array}{l}\text { Job-task } \\
\text { support }\end{array}$ & Compliance & $\begin{array}{l}\text { Volunteering for } \\
\text { additional duties }\end{array}$ \\
\hline Quantitative Demands (QD) & $-0.096 * *$ & $-0.106 * *$ & -0.055 & $-0.095 * *$ & $-.0127 * *$ & -0.066 & $-0.102 *$ & $-0.147 * *$ \\
\hline Physical Demands (PD) & $-0.109 * *$ & -0.069 & -0.044 & -0.066 & $-0.107 * *$ & -0.023 & $-0.128 * *$ & $-0.114 * *$ \\
\hline Emotional Demands (ED) & -0.060 & $-0.115 * *$ & $-0.101 * *$ & -0.035 & $-0.130 * *$ & $-0.073^{*}$ & $-0.081 *$ & $-0.081 *$ \\
\hline Shift Work (SW) & $-0.120 * *$ & $-0.191 * *$ & $-0.143 * *$ & $-0.094 * *$ & $-0.081 * *$ & -0.022 & $-0.082 *$ & $-0.101 * *$ \\
\hline F value & 44.170 & 31.860 & 47.780 & 41.090 & 65.160 & 29.79 & 18.530 & 35.880 \\
\hline $\mathrm{R}^{2}$ & 0.390 & 0.316 & 0.409 & 0.373 & 0.485 & 0.301 & 0.211 & 0.342 \\
\hline Adjusted $\mathrm{R}^{2}$ & 0.381 & 0.306 & 0.400 & 0.364 & 0.478 & 0.291 & 0.200 & 0.332 \\
\hline Durbin Watson & 1.840 & 1.870 & 1.980 & 1.860 & 1.750 & 1.850 & 1.850 & 1.760 \\
\hline
\end{tabular}

The negative relationship between job demands and job (task and contextual) performance of nurses is expected because according to job demands-resources model, when demands are high (e.g., quantitative demands and physical demands) it may not be easy for employees to allocate their attention and energy efficiently because they have to engage in greater activation and/or effort and this, in turn, negatively affects their performance (Bakker et al., 2004) Furthermore, Peters et al. (2009) found that nurses working in nursing and care homes reported job demands to negatively affect their job performance. 


\section{CONCLUSION}

This study has investigated the factors influencing nurses' job performance among the Ministry of Health hospitals in Saudi Arabia using job demands based on Conservation Of Resources theory (COR), social exchange theory and negative linear theory that may help nurses' managers to realize nurses' performance behavior. The findings showed that the nurses' job performance can be modeled by the Job Demands and Resources (JD-R) model original constructs in addition to other significant variables derived from other related theories. The present research model was tested and validated with 632 hospitals nurses in one region in Saudi Arabia. The study on the factors affecting the hospitals nurses in Saudi Arabian Ministry of Health was deemed necessary in order to increase the nurses' job performance.

The study found the level of nurses' job performance among hospitals nurses in Saudi Arabia to be moderate. Also the study found direct significant relationships among the tested job demands and resources variables with nurses' job performance. Moreover, the study found partial support for the role of job stress as a mediator in a relationship between Job Demands and Resources (JD-R) and nurses' job performance. Job stress mediated the relationship between job demands and resources variables (except job security) and two dimensions of job contextual performance (compliance and volunteering for additional duties).

In sum, despite the mixed results, in general, the present study managed to find support for the JD-R model and conservation of resources theory in that job demands and resources are able to produce a psychological reaction, which subsequently affect job performance. In this study, the psychological reaction was stress, which was considered an important and reasonable reaction to the stimuli in the work environment.

\section{REFERENCES}

Bakker, A.B., E. Demerouti and M.C. Euwema, 2005. Job resources buffer the impact of job demands on burnout. J. Occupat. Health Psychol., 10: 170-180. PMID: 15826226

Bakker, A.B., E. Demerouti and W. Verbeke, 2004. Using the job demands-resources model to predict burnout and performance. Hum. Resource Manage., 43: 83-104. DOI: $10.1002 / \mathrm{hrm} .20004$
Bakker, A.B., E. Demerouti, T.W. Taris, W.B. Schaufeli and P.J.G. Schreurs, 2003. A multigroup analysis of the job demands-resources model in four home care organizations. Int. J. Stress Manage., 10: 16-38. DOI: $10.1037 / 1072-5245.10 .1 .16$

Beutell, N.J., 2010. Work schedule, work schedule control and satisfaction in relation to work-family conflict, work-family synergy and domain satisfaction. Career Dev. Int., 15: 501-518. DOI: 10.1108/13620431011075358

Coakes, S.J., L.G. Steed and C. Ong, 2009. Spss: Analysis Without Anguish Using SPSS Version 17. 0 for Windows. 1st Edn., John Wiley and Sons Australia, Limited, Milton, ISBN-10: 174216546X, pp: 289.

Coetzer, C.F. and S. Rothmann, 2007. Job demands, job resources and work engagement of employees in a manufacturing organisation. Southern Afr. Bus. Rev., 11: 17-32.

Cohen-Charash, Y. and P.E. Spector, 2001. The role of justice in organizations: A meta-analysis. Organ. Behav. Hum. Decision Proc., 86: 278-321. DOI: 10.1006/obhd.2001.2958

Cook, T.D., D.T. Campbell and A. Day, 1979. QuasiExperimentation: Design and Analysis Issues for Field Settings. 1st Edn., Hougton Mifflin, ISBN-10: 0395307902, pp: 405.

Cooper, D.R. and P.S. Schindler, 2008. Business Research Methods. 10th Edn., McGraw-Hill Higher Education, Boston, ISBN-10: 0071263330, pp: 746.

Costa, G., 2003. Shift work and occupational medicine: An overview. Occupat. Med., 53: 83-88. DOI: 10.1093/occmed/kqg045

De Jonge, J. and C. Dormann, 2003. The DISC Model: Demand-Induced Strain Compensation Mechanisms in Job Stress. In: Occupational Stress in the Service Professions, Dollard, M., H.R. Winefield and A.H. Winefield (Eds.), Taylor and Francis, London, ISBN10: 0203422805, pp: 43-74.

Demerouti, E. and S. Geurts, 2004. Towards a typology of work-home interaction. Commun. Work Family, 7: 285-309. DOI: 10.1080/1366880042000295727

Demerouti, E., A.B. Bakker, F. Nachreiner and W.B. Schaufeli, 2001. The job demands-resources model of burnout. J. Applied Psychol., 86: 499-512. PMID: 11419809 
Emmerik, I.J.H.V. and M.C.W. Peeters, 2009. Crossover specificity of team-level work-family conflict to individual-level work-family conflict. J. Managerial Psychol., 24: 254-268. DOI: $10.1108 / 02683940910939331$

Fronea, M.R., J.K. Yardley and K.S. Markel, 1997. Developing and testing an integrative model of the work-family interface. J. Vocational Behav., 50: 145-167. DOI: $10.1006 /$ jvbe.1996.1577,

Hair, J.F. and R.E. Anderson, 2010. Multivariate Data Analysis. 7th Edn., Pearson Prentice Hall, Chichester, ISBN-10: 0138132631, pp: 785.

Hedges, J.N. and E.S. Sekscenski, 1979. Workers on late shifts in a changing economy. Monthly Labor Rev., 102: 14-22.

Igbaria, M., J. Iivari and H. Maragahh, 1995. Why do individuals use computer technology? A Finnish case study. Inform. Manage., 29: 227-238. DOI: 10.1016/0378-7206(95)00031-0

Jex, S.M., 1998. Stress and Job Performance: Theory, Research and Implications for Managerial Practice. 1st Edn., Sage Publications, Thousand Oaks, ISBN10: 0761909230, pp: 129.

Jimmieson, N.L., D.J. Terry and V.J. Callan, 2004. A longitudinal study of employee adaptation to organizational change: The role of change-related information and change-related self-efficacy. J. Occupat. Health Psychol., 9: 11-27. PMID: 14700455c

Jones, F. and B.C. Fletcher, 1996. Job Control and Health. In: Handbook of Work and Health Psychology, Schabracq, M., J.A.M. Winnubst and C.L. Cooper (Eds.), Wiley and Sons, Chichester, ISBN-10: 0471957895, pp: 33-50.

Judge, T.A., A. Erez and J.E. Bono, 1998. The power of being positive: The relation between positive selfconcept and job performance. Hum. Perform., 11: 167-187. DOI: 10.1080/08959285.1998.9668030

Kacmar, K.M., B.J. Collins, K.J. Harris and T.A. Judge, 2009. Core self-evaluations and job performance: The role of the perceived work environment. J. Applied Psychol., 94: 1572-1580. PMID: 19916664

Kaiser, H.F., 1960. The application of electronic computers to factor analysis. Educ. Psychol. Measure., 20: 141-151. DOI: $10.1177 / 001316446002000116$

Karriker, J.H. and M.L. Williams, 2009. Organizational justice and organizational citizenship behavior: A mediated multifoci model. J. Manage., 35: 112-135. DOI: $10.1177 / 0149206307309265$
Kristensen, T.S., J.B. Bjorner, K.B. Christensen and V. Borg, 2004. The distinction between work pace and working hours in the measurement of quantitative demands at work. Work Stress, 18: 305-322. DOI: 10.1080/02678370412331314005

Kwakman, K., 2001. Work stress and work-based learning in secondary education: Testing the Karasek model. Hum. Resou. Dev. Int., 4: 487-501. DOI: $10.1080 / 13678860010004123$

McFadzean, F. and E. McFadzean, 2005. Riding the emotional roller-coaster: A framework for improving nursing morale. J. Health Org. Manage., 19: 318-339. DOI: 10.1108/14777260510615378

Michiel, P., D.E. Looze, E. Zinzen, D. Caboor and P.V. Roy et al., 1998. Muscle strength, task performance and low back load in nurses. Ergonomics, 41: 1095-1104. DOI: 10.1080/001401398186405

Monk, T.H. and S. Folkard, 1985. Individual Differences in Shift Work Adjustment. In: Hours of Work: Temporal Factors in Work Scheduling, Folkard, S. and T.H. Monk (Eds.), Wiley, Chichester, ISBN-10: 0471105244, pp: 227-237.

Nahrgang, J.D., F.P. Morgeson and D.A. Hofmann, 2011. Safety at work: A meta-analytic investigation of the link between job demands, job resources, burnout, engagement and safety outcomes. J. Applied Psychol., 96: 71-94. PMID: 21171732

Neuman, W.L., 1997. Social Research Methods: Qualitative and Quantitative Approaches. 3rd Edn., Allyn and Bacon, Boston, ISBN-10: 0205193560, pp: 560.

Nunnally, J.C., 1978. Psychometric Theory. 2nd Edn., McGraw-Hill, New York, ISBN-10: 0070474656, pp: 701.

Peeters, M.C.W., A.J. Montgomery, A.B. Bakker and W.B. Schaufeli, 2005. Balancing work and home: How job and home demands are related to burnout. Int. J. Stress Manage., 12: 43-63.

Perrewe, P.L. and D.C. Ganster, 1989. The impact of job demands and behavioral control on experienced job stress. J. Org. Behav., 10: 213-229. DOI: 10.1002/job.4030100303

Peters, V.P.J.M., A.E.D. Rijk and N.P.G. Boumans, 2009. Nurses' satisfaction with shiftwork and associations with work, home and health characteristics: A survey in the Netherlands. J. Adv. Nursing, 65: 2689-2700. PMID: 19941550 
Rosa, R.R. and M.J. Colligan, 1997. Plain language about shiftwork. Public Health Service, Centers for Disease Control and Prevention.

Rose, M., 1984. Shift work how does it affect you? Am. J. Nurs., 84: 442-447.

Rotundo, M. and P.R. Sackett, 2002. The relative importance of task, citizenship and counterproductive performance to global ratings of job performance: A policy-capturing approach. J. Applied Psychol., 87: 66-80.

Schmidt, F.L. and J.E. Hunter, 1998. The validity and utility of selection methods in personnel psychology: Practical and theoretical implications of 85 years of research findings. Psychol. Bull., 124: 262-274. DOI: $10.1037 / 0033-$ 2909.124.2.262

Smith, S.S., S. Kilby, G. Jorgensen and J.A. Douglas, 2007. Napping and nightshift work: Effects of a short nap on psychomotor vigilance and subjective sleepiness in health workers. Sleep Biol. Rhythms, 5: $\quad 117-125$. DOI: $10.1111 / \mathrm{j} .1479-$ 8425.2007.00261.x
Tooren, M. and J. Jonge, 2010. The role of matching job resources in different demanding situations at work: A vignette study. J. Occupat. Org. Psychol., 83: 3954. DOI: 10.1348/096317909X462257

Tsutsumi, A., N. Iwata, T. Wakita, R. Kumagai and H. Noguchi et al., 2008. Improving the measurement accuracy of the effort-reward imbalance scales. Int. J. Behav. Med., 15: 109-119. DOI: 10.1080/10705500801929718

Vegchel, N., J. Jonge, M. Soderfeldt, C. Dormann and W. Schaufeli, 2004. Quantitative versus emotional demands among Swedish human service employees: Moderating effects of job control and social support. Int. J. Stress Manage., 11: 21-40.

Witt, L.A., K.M. Kacmar, D.S. Carlson and S. Zivnuska, 2002. Interactive effects of personality and organizational politics on contextual performance. J. Org. Behav., 23: 911-926. DOI: 10.1002/job.172

Zikmund, W.G., B.J. Babin, J.C. Carr and M. Griffin, 2012. Business Research Methods. 9th Edn., Cengage Learning, Mason, ISBN-10: 1111826927 , pp: 696. 